\author{
Lucia BEDNÁROVÁ ${ }^{1}$ \\ Natália JERGOVÁ ${ }^{2}$ \\ Zuzana HAJDUOVÁ ${ }^{3}$ \\ Andrzej PACANA ${ }^{4}$
}

\title{
PROPOSAL OF EMPLOYEE COMPETENCY IMPROVEMENT
}

\begin{abstract}
Employee's competencies represent the most powerful tool that leads to an improvement in business. In a changing economic and educational environment which is characterized by global competitive market knowledge is importance of workers developing considered like the corner stone. The world is going through many global changes. The most important changes are informatization, innovation, integration globalization. There is a requirement to identify and describe those competencies that must be applied in many employments and have to allow successfully to overcome the changes. The aim of this paper is to explain and characterize the system leading to a continuous competency improvement. The proposed system of continuous improvement represents a mechanism consisting of several cooperating elements, methods and procedures application of which will be achieved competency improvement in the company. The system is suitable for every company which wants to improve the employee competencies. System of improving employee competencies can be created for specific selected positions at every level in the company and for the company as a whole. Creation of competency model, identification of competency list is not easy. There exist procedures to correctly identify competencies and develop an appropriate competency model. The system of endless competency improvement has to be implemented on the PDCA cycle principle according to Deming.

Keywords: employee competencies, competency model, competency list
\end{abstract}

\section{INTRODUCTION}

Since 70 s the society has already known that competency improvement is necessary ${ }^{5}$. Human competencies are discussed from many points of view - in terms of study, career or normal life. There were published research results in 2001. The research lasted about 15 years and was made in about 60 companies, where experts were focused on determination and investigation of competencies. Research has shown that companies that were focused on

\footnotetext{
${ }^{1}$ Doc. Ing. Lucia Bednárová, PhD, Department of Commercial Business, University of Economics in Bratislava, Faculty of Business Economy with seat in Košice, Tajovského 13, 04130 Košice, Slovakia.

${ }^{2}$ Ing. Natália Jergová, PhD, Department of Commercial Business, University of Economics in Bratislava, Faculty of Business Economy with seat in Košice, Tajovského 13, 04130 Košice, Slovakia.

${ }^{3}$ doc. RNDr. Zuzana Hajduová, PhD, Department of Quantitative Methods University of Economics in Bratislava, Faculty of Business Economy with seat in Košice, Tajovského 13, 04130 Košice, Slovakia

${ }^{4}$ Andrzej Pacana, DSc, PhD, Eng., Associate Professor, Department of Manufacturing and Production Engineering, Rzeszow University of Technology, Powstancow Warszawy 8, 35-959 Rzeszow, Poland (corresponding author).

${ }^{5}$ M. Blaško, Kvalita v systéme modernej výučby, Aktualizované vydanie, Technická univerzita, Košice 2013. $400 \mathrm{~s}$.
} 
competencies have increased degree of success in recruitment of high-quality employees. There has been shown that the work ethics and success of targets achievement have increased in these companies.

\section{THEORETICAL EXPLANATIONS OF TERMS}

At the beginning it is necessary to define the terms - competency, core competency, competency model and competency matrix.

The term competence has two meanings. Competency as a responsibility is seen as an authorization to do the work. From another perspective, competency is seen as a summary of the human capabilities and his behavior which ensures the quality of fulfillment of working tasks. ${ }^{6}$ In the article we pay attention to the second meaning of term competency - skills and abilities which the worker has to have in certain work position.

European Training Foundation defines core competencies as a general set of skills and approaches that may be useful in all work situations - it is one of the surest ways of keeping education and relevant training in a rapidly changing environment ${ }^{7}$.

Competency model presents a summary of "key competencies with their behavioral signs that are required for a particular position or level of management. If the model is created for a particular position in a particular company, we are talking about specific model."8

Competency models specifically include the following elements:

- "competency names and detailed definitions,

- descriptions of activities or behaviors associated with each competency,

- a diagram of the model presenting of the model in graphical form to help,

- users quickly grasp the key feature of the model"9.

Bozkurt elaborates the types of competency models. We use job competency models and core competencies models in the paper. "A job competency model describes job or role competencies often those specific to a certain type of job within a specific work unit. These models provide a good foundation for building performance appraisals or individual training and development plans. A job competency model is a description of those competencies possessed by the top performers in a specific job or job family. Models usually contain 8-16 competencies. Core competency models are built through a process of continuous improvement and enhancement. They focus for corporate strategy. Core competencies are those capabilities that are critical to a business achieving competitive advantage. The key core competencies here are those that enable the creation of new products and services. Very important is customer relationship management." 10

\footnotetext{
${ }^{6}$ R. Kocianová, Personální ćinnosti a metody personální práce, 1. vyd., Grada Publishing, Praha 2010, $224 \mathrm{~s}$.

${ }^{7}$ European Training Foundation, Key Competences, http://www.etf.europa.eu/web.nsf/pages/Key_competences, 2014 (last viewed: 10.01.2015).

${ }^{8}$ P. Pokorný, Návrh zlepšení práce managerů, diplomová práca, VUT, Brno 2010, $76 \mathrm{~s}$.

9 T. Bozkurt, Management by Competencies, http://www.risus-tr.com/risus/wp-content/uploads/ managementbycompetenciestulaybozkurt, 2011 (last viewed: 10.01.2015)

110329032120-phpapp02.pdf.

${ }^{10} \mathrm{~T}$. Bozkurt, Management by Competencies, http://www.risus-tr.com/risus/wp-content/uploads/managementby competenciestulaybozkurt110329032120-phpapp02.pdf, 2011. (last viewed: 10.01.2015).
} 
"The competency matrix includes a list of behavioral statements and the associated quality values for each competency at several employee levels as managers, supervisors, executives, subordinates. The purpose is to help employees understand their contribution, through their individual performance, to the companies commitment." 11

Steps for competency model development process according to Bozkurt:

1. "performance criteria - defining the criteria for superior performance in the role,

2. criterion sample - choosing a sample of people performing the role for data collection,

3. data collection - collecting the sample data about the role for data collection,

4. data analysis - developing hypothesis about the competencies of outstanding performers and how these competencies work together to produce desired results,

5. validation - validating the results of the data and analysis,

6. application - applying the competency model in human resource activities, as needed".

\section{HOW TO CREATE A SYSTEM OF ENDLESS COMPETENCY \\ IMPROVEMENT?}

We know from the definition of the system as a whole that it is necessary to determine the selected elements, among which there are connections and relationships that form the system of continuous competency improvement. Elements of system of competency improvement in the company consist of:

- employees and their competencies,

- $\quad$ processes, activities of employees ,

- equipment that employees need,

- human resource department of a company,

- educational institutions, agencies providing professional courses, literature, internet sources and other sources that support the development of competencies.

Necessary methods, mental and work processes linking elements of the system are described in the upcoming part.

\subsection{Methods of data collection and their sources}

When creating the system it is necessary to cooperate with company to obtain primary data. It is important to get information from the human resource department, the director and the particular workers who are currently working at the working positions, which we want analyze. With help of these workers, HR department and director it is required to do interviews to obtain primary data. Primary data should be obtained from other sources in the form of internal accounting statements for the last years, the Code of Ethics, the Job Code, the Quality Handbook and job descriptions. Using these primary data we can create an analysis of situation in the company and propose solutions for creation of system of endless competency improvement.

\subsection{Used methods}

Several methods were used in the paper. We used theoretical and empirical methods. Among the theoretical methods belong:

${ }^{11}$ Ibidem. 
- abstraction, concretization,

- analysis, synthesis,

- comparison, interpretation,

- induction, deduction and

- $\quad$ analogical, method.

Among the empirical methods that were used in the paper include:

- content analysis,

- $\quad$ semantic analysis,

- method of managed discussion - interview,

- method of creation of recording sheets and excerpts.

For creation of the system of endless competency improvement it is necessary to use methods of obtaining new knowledge about reality in the chosen company. It is important to perform an analysis of internal documents, the company statutes, the process of recruitment, the Organizational Code, organizational structure, the Quality Handbook, Annual Report for the last year and job descriptions of selected positions. Important is to obtain expert opinion, make an interview and survey of requirements of employers. These belong to the methods of key competencies determining. From the methods of processing of obtained data we recommend to use theoretical methods - analysis, synthesis, comparison, generalization and interpretation. A specialized method of evaluation is necessary. This evaluation is explained in the own model of determining competencies.

Sets of competencies and core competencies are determined by the own model of determining of competencies which consists of three criteria. The own model is shown in the Figure 1. The first criterion is the investigation of the job descriptions according to knowledge of the situation in the company. The second criterion is examination of job descriptions according to professional resources and the third criterion is examination of the job descriptions in terms of knowledge of the author.

Fig. 1. The own model of determining of competencies

\begin{tabular}{|l|l|l|}
\hline $\begin{array}{l}\text { Criterion 1 } \\
\text { Knowledge of the company situation }\end{array}$ & $\begin{array}{c}\text { Criterion 2 } \\
\text { Professional } \\
\text { resources }\end{array}$ & $\begin{array}{c}\text { Criterion 3 } \\
\text { Authors } \\
\text { knowledge }\end{array}$ \\
\hline$\bullet \quad$ time dimension & & \\
\hline$\bullet \quad$ financial dimension & & \\
\hline$\bullet \quad$ dimension of decision-making & & \\
\hline$\bullet \quad$ dimension of expert opinion & & \\
\hline
\end{tabular}

Source: own processing

Criterion 1 - knowledge of the situation in the company:

We recommended to use the own model of determining competencies mentioned in Figure 1. This procedure is based on the analysis of selected job descriptions. Job descriptions present knowledge and skills which the worker has to have and describe activities of this job. Competencies with help of this procedure are analyzed according to the activities that are performed on the particular position. Based on the job descriptions and analysis, it is possible to identify a set of competencies and then a set of core competencies for all selected jobs. 
Individual work positions are analyzed according to Criterion 1 from four dimensions.

1. Time dimension - individual work activities are distinguished in percentage according to that how much time from daily eight working hours the worker does them. Working activities together constitute $100 \%$ of working time. Those activities that reach the most time are considered from this point of view like the most important. Relevant time resolution of activities is done by worker who is working at that position in the time of research.

2. Financial dimension - if the worker decides at some of his activities about financial resources of the company than we assigned to the activity interval ranging from minimum to maximum of money. Activities and their intervals are then ranked from the biggest to the lowest according to that it is possible to determine the importance from this point of view. Determination of the intervals of financial amount is made by worker who is working at that position in the time of research.

3. Dimension of decision-making - work activities have different importance from the decision-making dimension. For this evaluation, we choose a simple upward range from $1,2, \ldots \mathrm{x}$, the number 1 represents the most important activity and number $\mathrm{x}$ represents the least important activity. Sequencing of activities from the most important to the least important (from 1 to $\mathrm{x}$ ) is done by the worker in the position. Worker determines the sequence of activities and their competencies according to individual opinion and to such number $\mathrm{x}$ to which he considers the determination of the sequence relevant.

4. The fourth dimension is the expert opinion. Expert identifies competencies the worker should have on the particular job position. He identifies key competencies. As an expert can be considered a worker who works in the particular position for long time ( 5 years or more).

For thus analyzed activities accrue ranks. From ranked activities according to dimensions of Criterion 1 is possible to identify set of competencies. The set of competencies and their activities compose competency matrix. From the competency matrix we can identify core competencies. This identifying is based on the ranks which are results of analysis according this Criterion 1. The activities, which have the most important evaluation, are considered like core competencies. In following part we pay attention to the selected core competencies.

We need to add to the core competency model competencies which are considered as essential/core according to the professional resources and to knowledge of the author.

Criterion 2 - professional resources:

From this dimension are milestones available literature and internet resources, competencies model that are considered suitable for the selected positions. Various job portals, studied foreign, Slovak literature and internet resources can be used, too. On job portals such as profesia.sk, kariera.zoznam.sk, praca.sme.sk, trenkwalder.sk, job.sk, etc. are searched ads for jobs that are identical or related to the selected positions. A set of key competencies occurs as a summary of information from all these resources.

Criterion 3 - knowledge of the author:

From this dimension we use subjective opinion for determining the core competencies which will be generated on the basis of professional knowledge which were obtained by appropriate education in the area, self studying and interest in the area.

Consequently, it is possible to create core competencies models according to all three criteria of the own model of determining of competencies. According to Bozkurt we know which elements should contain the competency model. These elements must be included 
in core competencies models, which came into existence by analysis according to the own model of determining of competencies.

Fig. 2. Core competencies model

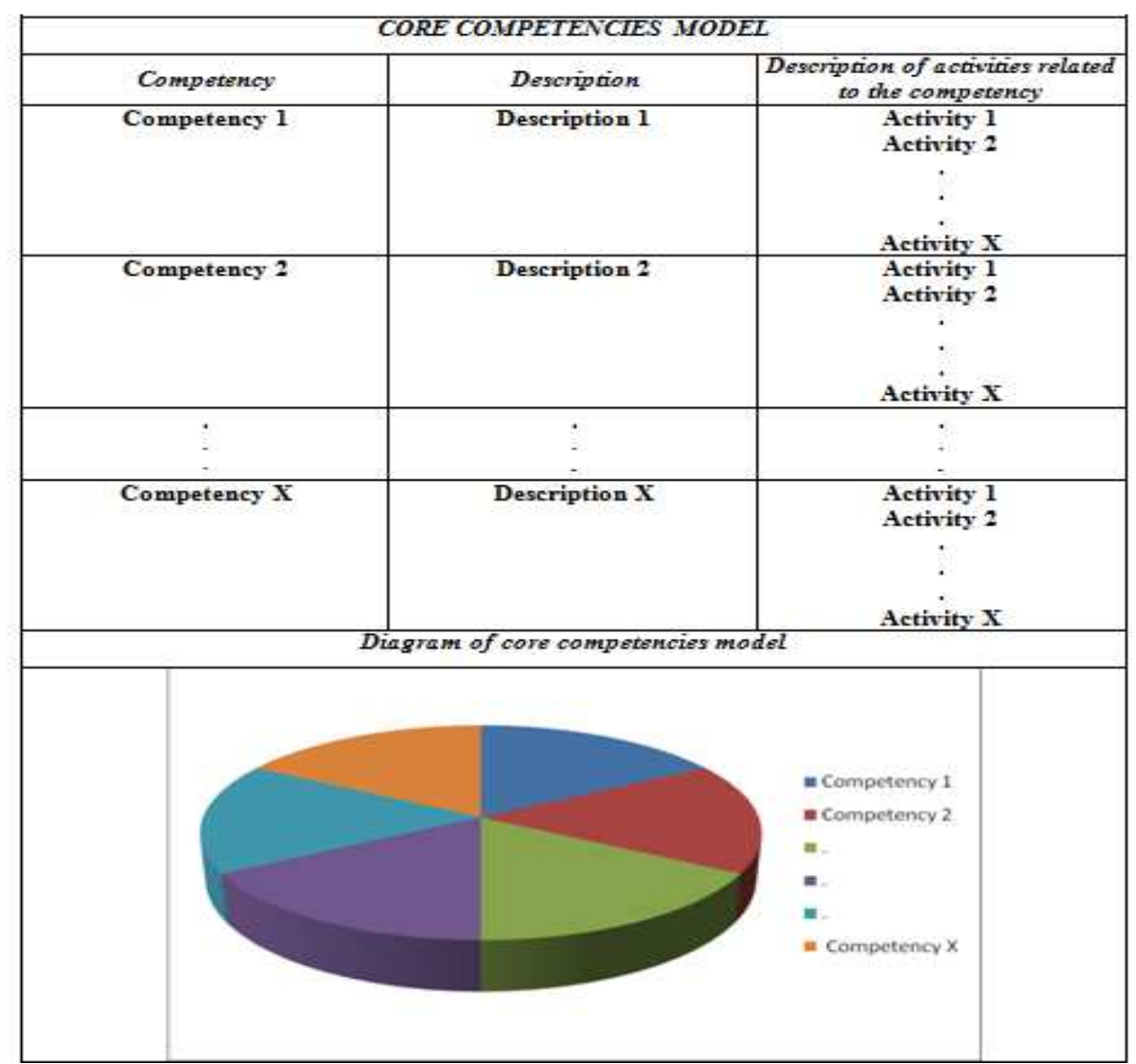

Source: own processing according to Bozkurt (2011)

The resulting core competencies models are considered ideal. Ideal competencies models are compared with the situation in the company - identified by Criterion 1 . This showed which competencies are not developed as they should be developed according to the established ideal models, respectively which competencies are in the set completely missing. To these competencies must be given appropriate attention. By this procedure is also filled the procedure for creation of competency models by Bozkurt. This is the procedure ${ }^{12}$ :

1. performance criteria,

2. criterion sample,

3. data collection,

4. data analysis,

${ }^{12}$ Ibidem. 
5. validation,

6. application.

Generally the exact number of core competencies in the model is not precisely defined. Based on creation by Bozkurt, the models must contain three elements - a description of competencies, description of activities related to the competency and graphical diagram of model as is shown in Figure $2^{13}$.

\subsection{Proposals for implementation of the system of endless competency improvement}

Standard STN EN ISO 9001: 2009 explains the competency of workers. It is necessary to determine whether the company has implemented mentioned standard. If the standard is implemented, it is necessary to explain how the standard is fulfilled by the company. If it is not implemented, we recommend its implementation to the company.

Recommendation for determining of competencies to the future is also the need of variation of competency analysis methods, e.g. for executive and administrative company units. Competency determining methods are varied according to character of performing activity.

After the core competency determination we need to investigate how the interview is managed, whether it is sufficiently adapted for identification if an adept has competencies important for the job position. If the process of interview does not correspond with this, the company has to customize the process.

Bozkurt showed how the competency model should look. Based on this conception we recommend publishing diagrams of core competency models in offices, building of company. This should motivate the workers to reach and develop these core competencies.

If an adept on job position signs a job contract, he is employee of a company. The worker has to competent for the job. In this case we recommend develop his competencies with help of professional courses and education training.

We recommend do periodical actualizations of activity and competency changes. We support keeping of actual lists of competencies. The actualizations of activities and competencies should be done by the upper mentioned method based on the own model of determining of competencies in the Figure 1. The actualizations should be done by cooperation of CEO, HR department and workers. HR department and CEO have to implement the model. CEO has to supervise the analysis. Periodicity of actualizations depends on the industry in which the company operates dynamics of economic changes and other factors.

The analysis of activities and competencies is possible to perform with time screens. Time screens should provide a cross section of work day. If there are changes in the activities during the month or year, we need to estimate the range of these activities. For this range we can use averaging of all time values. This should be done by HR department of the company. We recommend making time screens periodically. The results of analysis according to the model described in the paper and time screens are possible to compare and then determine the most important competencies.

\subsection{PDCA cycle as a mean of the system of endless competency improvement}

After the explanation of proposals it is possible to describe proposed system like PDCA cycle. It consists of 4 phases - planning, test, control and implementation phase. The phases represent endless, repetitive process. This process with individual steps is 
shown in the Figure 3. Here is description of the system of endless competency improvement, which is divided into steps, responsibilities, results and methods.

\section{Planning phase}

In this phase is necessary to plan steps, identify who is responsible for each step and determine the results and methods. Here is structure of planned activities, which together create the system.

I. Identification of competencies for all working positions - HR department, CEO - lists of core competencies - The own model of determining of competencies, various mentioned methods, time screens;

II. Customization of recruitment process according to core competencies HR department, CEO, expert - customization of interviews - test, questionnaires;

III. Analysis if current competencies of workers correspond with core competencies - HR department, CEO, expert - current situation in the company - test, questionnaires;

IV. Selection of methods, creation of schedule of core competency improvement - HR department, CEO - selected methods, schedule - professional courses provided by the company or external organization;

V. Actualization of core competencies - HR department, CEO - actual lists of core competencies - The own model of determining of competencies, time screens.

\section{Test phase}

In the planning phase we recommended 5 basic steps. In test phase is necessary to test these steps.

I. Testing of planned steps - HR department, CEO - created plan company implementation;

II. Determination whether it is necessary to add a step - HR department, CEO - added step - company implementation;

III. Summary of results - HR department, CEO - summary of results company implementation.

\section{Control phase}

Control phase should control planning and test phase. Individual steps of the phase are described in following part.

I. Verification of previous phases, comparison of results - HR department, CEO - added step, Identification of deviations - control;

II. Identification the underlying causes deviations - HR department, CEO causes of deviations - analysis of previous results;

III. Corrections - HR department, CEO - removing deviations - various methods depending on deviations. 
Fig. 3. The system of endless competency improvement - PDCA cycle

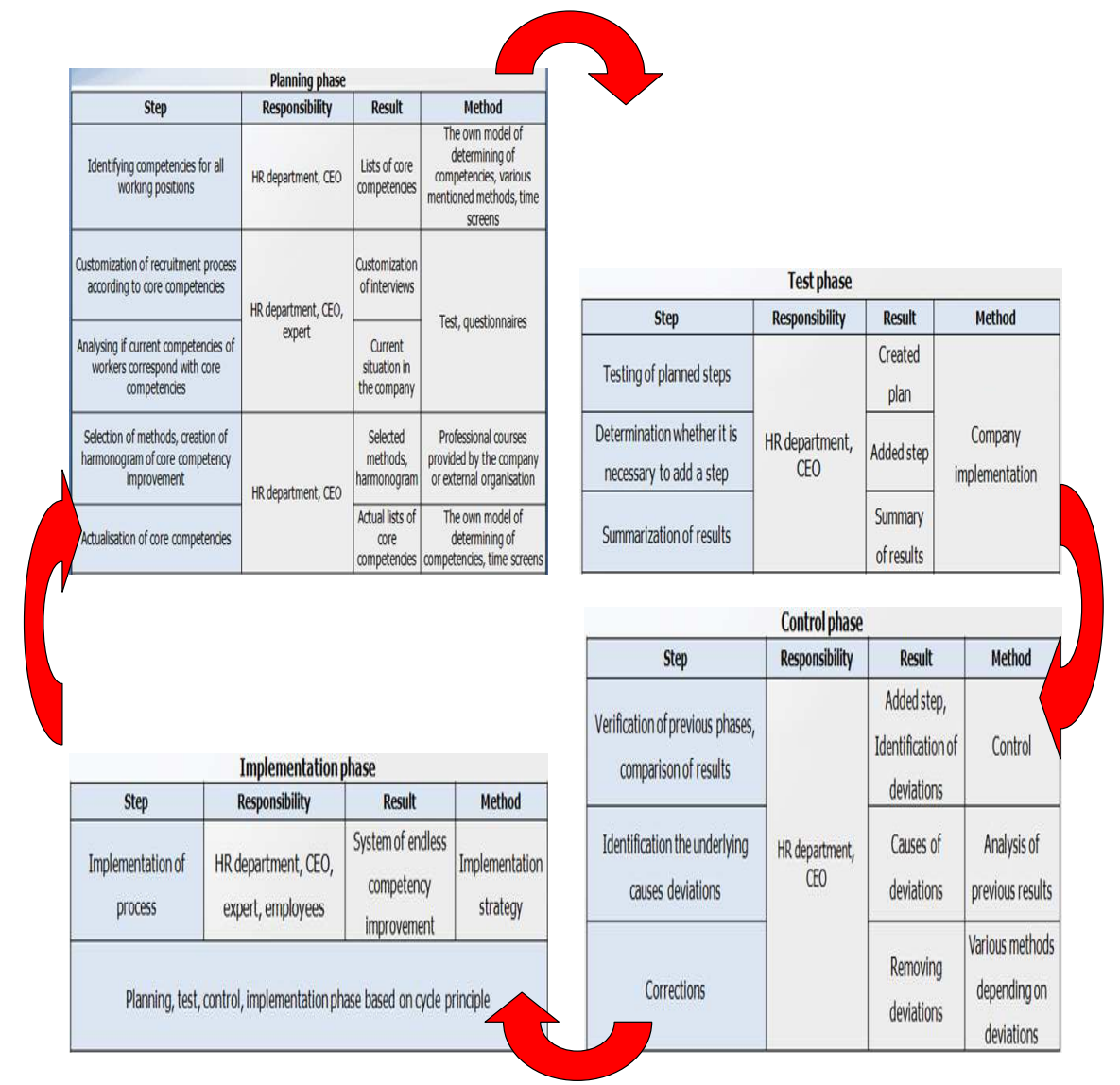

Source: own processing according to Deming (1993)

\section{Implementation phase}

Implementation phase must implement planned system into company. The system was in planning phase divided into steps, responsibilities, results and methods. The test phase tests the proposed system in the company. The control phase controls the results of test phase and compares them with planned results. The phase determines the deviations and their corrections. Then the system of endless competency improvement is ready for implementation.

I. Implementation of process - HR department, CEO, expert, employees system of endless competency improvement - implementation strategy;

II. Planning, test, control, implementation phase based on cycle principle.

\section{CONLUSION}

The base for improving a person's professional career is to develop competencies, develop their competence. The paper is aimed at creating a continuous improvement system of employee's competencies. One of the proposals that enterprises should consider 
is the introduction of a comprehensive system of improving employee's competencies, which were treated in the article. The system is based on the infinite process in the form of PDCA cycle and begins the process of selecting employees for the job. For employees who are already working in the business, the system starts in the form of determining the list of key competences at their jobs. In the system we present the various phases of the system, the methods of implementing the various phases and the results of these phases.

\section{REFERENCES}

[1] Blaško M., Kvalita v systéme modernej výučby, Aktualizované vydanie, Technická univerzita, Košice 2013, 400 s.

[2] Bozkurt T., Management by Competencies, http://www.risus-tr.com/risus/wp-content/uploads /managementbycompetenciestulaybozkurt-110329032120-phpapp02.pdf 2011 (last viewed 10.01.2015).

[3] European Training Foundation, Key Competences, http://www.etf.europa.eu/web.nsf/ pages/Key_competences, 2014 (last viewed 10.01.2015).

[4] Hroncová M., Návrh systému zdokonal'ovania kompetencií pracovníkov v podniku eurobus, a.s., diplomová práca, EUBA, Košice 2014, 121 s.

[5] Kocianová R., Personální činnosti a metody personální práce, 1. vyd., Grada Publishing, Praha 2010, $224 \mathrm{~s}$.

[6] Pokorný P., Návrh zlepšení práce managerů, diplomová práca, VUT, Brno 2010, $76 \mathrm{~s}$.

[7] STN EN ISO 9001:2009, Systémy manažérstva kvality - Požiadavky, 2009.

\section{PROPOZYCJA UDOSKONALENIA KOMPETENCJI PRACOWNIKA}

Kompetencje pracownicze stanowią jeden $\mathrm{z}$ najbardziej pożądanych zasobów, które prowadzą do wzrostu konkurencyjności w biznesie. W zmieniającym się środowisku gospodarczym, które charakteryzuje się konkurencyjnym rynkiem globalnym i bazuje na wiedzy, znaczenie rozwijających się pracowników staje się kluczową kwestią. Świat przeżywa wiele globalnych zmian. Najważniejsze zmiany to: informatyzacja, innowacyjność, integracja globalizacja. Nie jest w zasadzie możliwe, aby zidentyfikować i opisać wszystkie kompetencje, które muszą cechować różne zawody i mają umożliwić sprostanie wyzwaniom zmiany.

Celem niniejszego artykułu jest wyjaśnienie i scharakteryzowanie systemu prowadzącego do ciągłego doskonalenia kompetencji pracowniczych. Proponowany system ciągłego doskonalenia przedstawia mechanizm składający się z kilku współpracujących elementów, metod i procedur. Ich zastosowanie może się przyczynić do poprawy kompetencji pracowniczych w firmie. Zaprezentowany system zastosować można w każdej firmie, która chce podnieść kompetencje pracowników. Takie lub podobne systemy poprawy kompetencji pracowników mogą być tworzone dla konkretnych wybranych stanowisk pracy, dla każdego szczebla hierarchii w firmie, a także dla firmy jako całości.

Stworzenie modelu kompetencji, identyfikacja listy kompetencji nie są prostym zadaniem. Istnieją procedury w celu prawidłowego określenia kompetencji i rozwoju odpowiedniego modelu kompetencji. System niekończącej poprawy kompetencji powinien być realizowany w oparciu na zasadzie, zgodnie z cyklem ciągłego doskonalenia PDCA Deminga. Składa się z czterech faz: planowania, realizacji, kontroli i korekcji. Fazy te stanowią powtarzalny proces będący podstawą niekończącego się doskonalenia kompetencji w zmieniającej się firmie.

Słowa kluczowe: kompetencje pracownicze, model kompetencji, listy kompetencji

\section{DOI: 10.7862/rz.2015.mmr.1}

Tekst złożono w redakcji: marzec 2015

Przyjęto do druku: marzec 2015 